\title{
Seismic activity and neotectonic evolution of the Western Carpathians (Slovakia)
}

\author{
M. Kováč ${ }^{1}$, M. Bielik ${ }^{2}$, J. Hók ${ }^{3}$, P. Kováć ${ }^{3}$, B. Kronome ${ }^{1}$, P. Labák ${ }^{2}$, P. Moczo ${ }^{2}$, D. Plašienka ${ }^{4}$, J. Šefara ${ }^{5}$, and \\ M. Šujan ${ }^{6}$ \\ ${ }^{1}$ Department of Geology and Paleontology, Comenius University, Mlynská dolina G, 84215 Bratislava, Slovakia \\ ${ }^{2}$ Geophysical Institute, Slovak Academy of Sciences, Dúbravská cesta 9, 84228 Bratislava, Slovakia \\ ${ }^{3}$ Geological Survey of Slovak Republic, Mlynská dolina 1, 81704 Bratislava, Slovakia \\ ${ }^{4}$ Geological Institute, Slovak Academy of Sciences, Dúbravská cesta 9, 84228 Bratislava, Slovakia \\ ${ }^{5}$ Department of Geophysics, Comenius University, Mlynská dolina G, 84215 Bratislava, Slovakia \\ ${ }^{6}$ EQUIS Ltd., Račianska 57, 83102 Bratislava, Slovakia
}

Received: 2 May 2000 - Accepted: 8 March 2001

\begin{abstract}
Seismic activity in the Western Carpathians is closely related to the crustal rheology and combined structural pattern within the brittle upper crust. The structural pattern is a combination of three structural levels. The deepest level is represented by the Paleo-Alpine suture zones dissected by neo-Alpine fault structures, above all strikeslip fault zones (second level). The recent tectonic regimes are controlled by the contemporary stress field and vertical movements (third level). Following the analyses of structures and various geophysical data, the principal seismo-tectonic zones of the Western Carpathians are defined.

The most remarkable and important first-order tectonic structure in the Western Carpathians is the zone of the Pieniny Klippen Belt, which represents the contact of the Western Carpathian internides and the stable European Platform.
\end{abstract}

The Mur-Mürz-Leitha fault zone in the area of the Vienna Basin represents the contact of the Eastern Alps with the block of Western Carpathian internides. Both these tectonic lines represent subvertical boundaries with Tertiary tectonic activity.

The Čertovica fault zone is a surface projection of the thrust plane of the Veporic thick-skinned sheet over the Tatric unit. Based on geological and geophysical data it is assumed that the Čertovica zone is recently active due to its extensional reactivation. Earthquake events are released here mostly along the Hron fault system of the ENE-WSW direction.

The next important tectonic structure is the HurbanovoDiósjenó line, which is most probably the continuation of the Rába line into the Slovak territory. Based on reflection seismic interpretations, there are several low-angle fault surfaces dipping to the SE. These thrust planes were reactivated dur-

Correspondence to: M. Kováč (kovacm@nic.fns.uniba.sk) ing the Miocene as low-angle extensional faults. The seismic events (e.g. Komárno area) are most probably generated on these low-angle surfaces.

Key words. Western Carpathians, rheology, structural patterns, recent stress field, seismic activity, seismic hazard

\section{Introduction}

Seismicity, as one of the important environmental hazards, is closely related to the stress release in the crust, often bound to the brittle fault deformation. Therefore prevention of possible catastrophic consequences of earthquakes needs a good seismotectonic model of the investigated area based on, in addition to seismological studies, a complex research of fault structures by all available means of geological and geophysical methods.

Seismic activity of Slovakia is closely related to crustal rheology and structural pattern. In most cases the seismic events are immediately related with the movements on fault surfaces. Therefore it is possible to correlate more or less successfully the earthquake hypocenters with the fault structures, which are in an appropriate anglular relationship with major elements of the stress field.

The present paper gives an overview of the research in seismic hazard assessment, in order to document the present stage of knowledge about the neotectonics of the Slovakian territory. Based on the geological structure, tectonic deformation, localised earthquake epicenters and geophysical characteristics we have tried to identify the geological structures, which in our opinion could potentially generate the seismic events. 


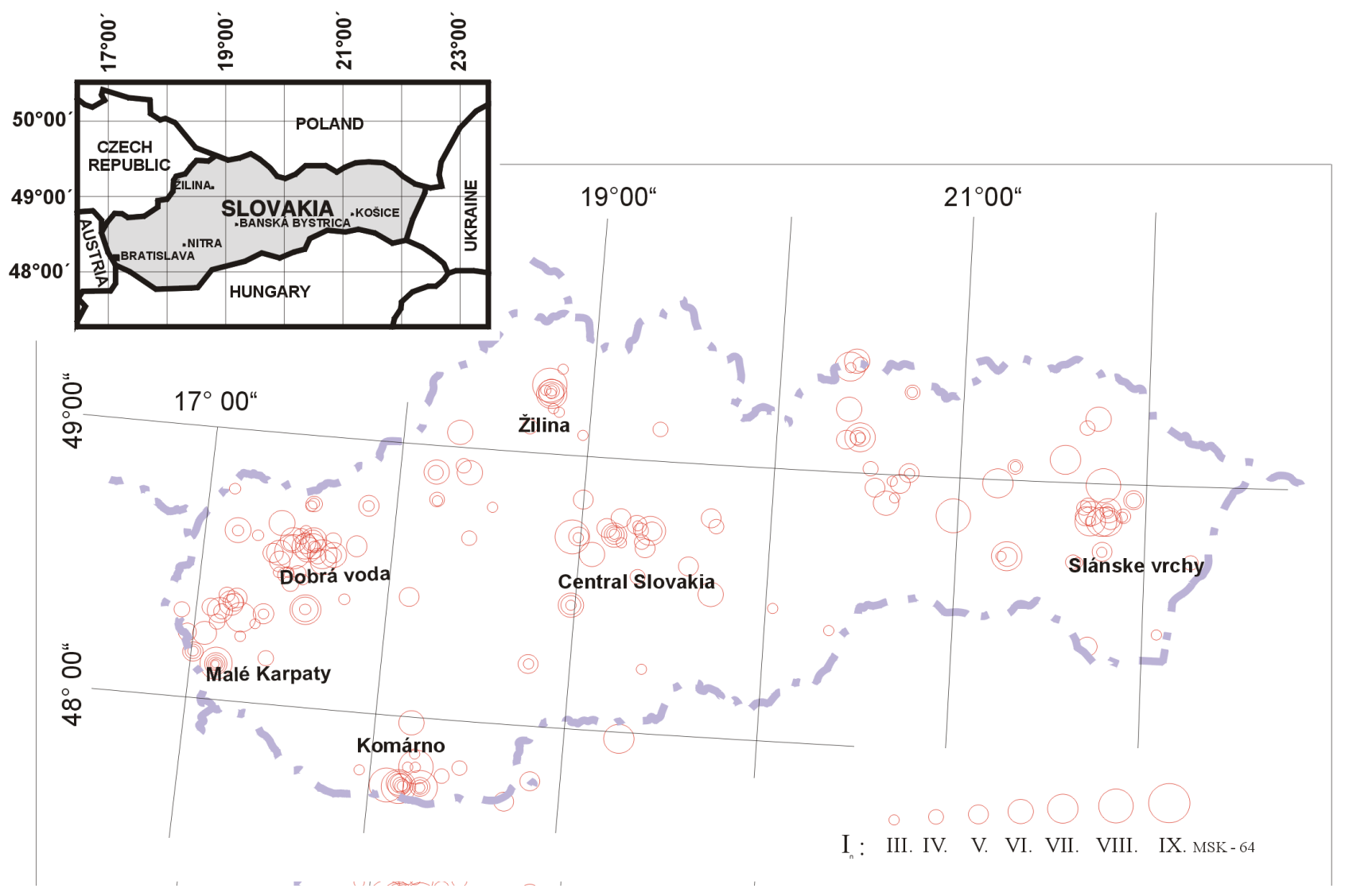

Fig. 1. Map of epicentres of macroseismically observed earthquakes for the period 1034-1990 (Labák and Brouček, 1996)

\section{Seismic activity}

Territory of the Western Carpathians and the whole Slovakia can be characterised by a moderate earthquake activity. This is documented by descriptive (Réthly, 1952; Kárník et al., 1957) and parametric catalogues (Zsíros et al., 1988 and Labák and Brouček, 1996) as well as several case studies (e.g. Szeidovitz, 1986; Brouček et al., 1991; Labák et al., 1996). More than 590 macroseismically felt earthquakes with epicentres on the territory of Slovakia since 1034 are documented in the Labák and Brouček's (1996) catalogue. Given the fact that more than 550 of them occurred after the 28 June 1763 Komárno earthquake, it is clear that the real number of the macroseismically felt earthquakes during the documented period should be considerably larger than 590. In addition to the macroseismic catalogues, the seismic activity is documented by seismometrically localised earthquakes. 35 earthquakes with local magnitude larger than approximately 2.5 have been localised for the whole territory of Slovakia since 1956. Data on microseismic activity is, in fact, restricted to the Dobrá Voda focal zone. Since 1987, more than 60 earthquakes with local magnitude greater than or equal to 1 have been recorded and localised by a local network there.

Data indicate the existence of several earthquake focal zones (Fig. 1) - Malé Karpaty Mts., Dobrá Voda, Žilina, Cen- tral Slovakia, Komárno and Slanské vrchy Mts. Dobrá Voda is the best spatially defined focal zone. This is thanks to the consistent clustering of the macroseismically and instrumentally localized earthquake epicenters.

Epicentral intensities of the three largest documented earthquakes, the June 5, 1443 Central Slovakia earthquake, 28 June 1763 Komárno earthquake and 9 January 1906 Dobrá Voda earthquake, all with epicentral intensity of $\mathrm{I}_{0}=$ 8-9 ${ }^{\circ} \mathrm{MSK}$, allow for the lower bound estimate of the maximum magnitude of $\mathrm{M}_{\mathrm{S}}=5.7$. The recent estimate of the maximum magnitude in the Western Carpathians of Ms = 6.2-6.8 was determined by Labák et al. (1997) who performed the integrated seismic hazard analysis for the Bohunice nuclear power plant site.

\section{Depth of the earthquake foci and rheology}

Earthquake hypocenters deeper than 20-30 km are known only from the marginal parts of the Carpathians and/or from the southeastern margin of the Pannonian Basin. The only active Benioff zone in the Carpathian arc related to the subduction process is situated in the Vrancea area, at a junction of the Eastern and Southern Carpathians in Romania. Hypocenters are in depths $10-180 \mathrm{~km}$ there, with an enigmatic seismic gap, which can be observed between 40 


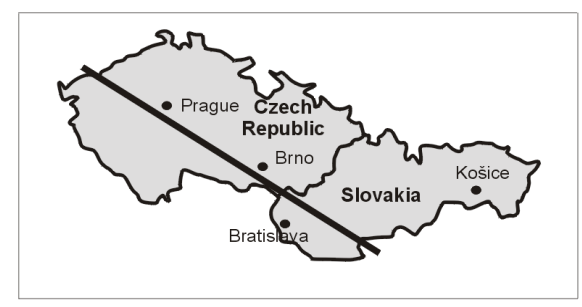

NW

Optimized Heat Flow

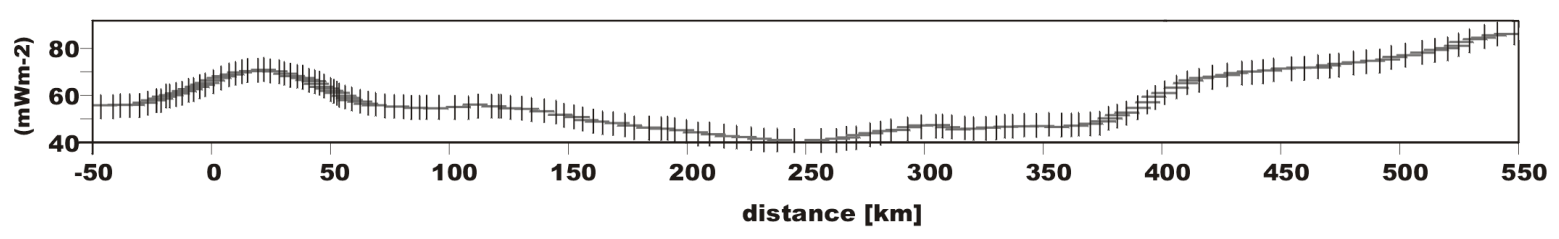

study area

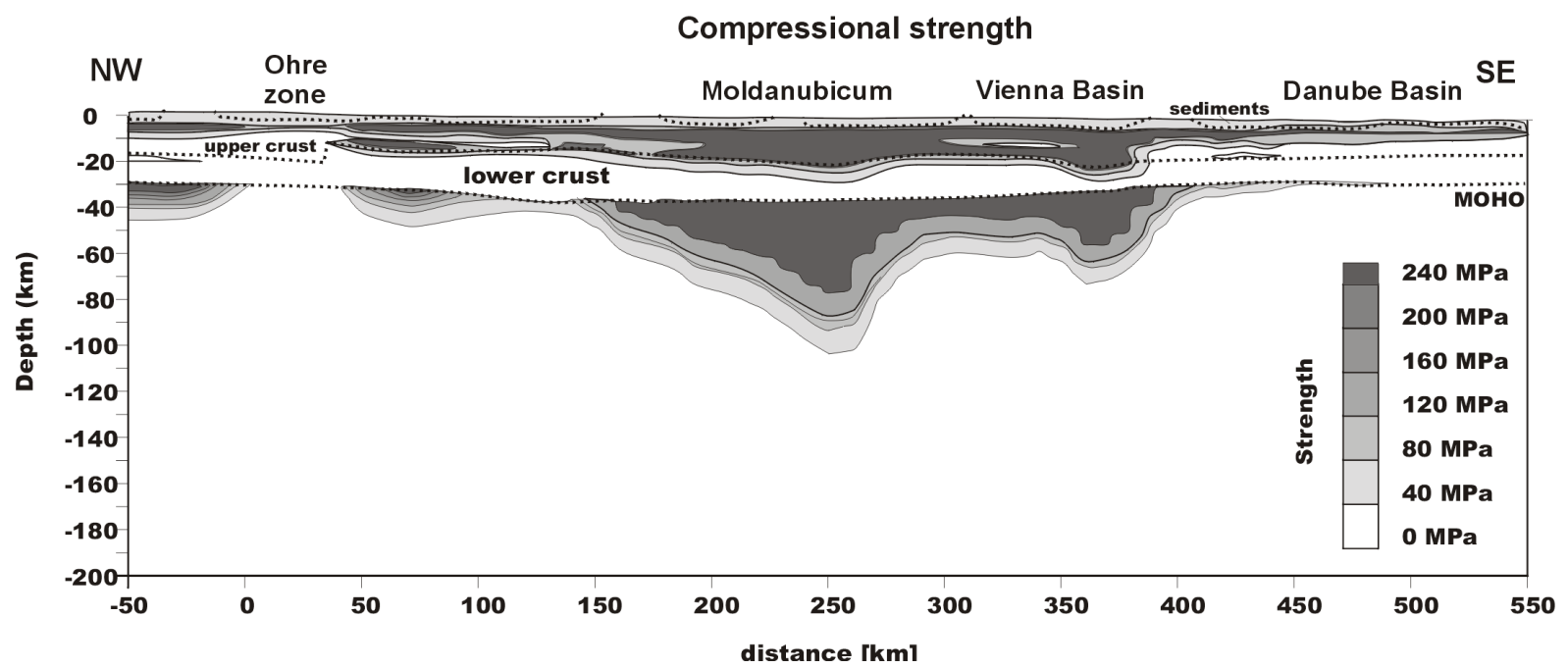

Fig. 2. Yield-strength contour plot for compressional deformation for NW-SE cross-section of Central Europe from the Bohemian Massif via the Western Carpathians to the Pannonian basin, at a strain-rate of $\varepsilon=10^{-15} \mathrm{~s}^{-1}$ (modified after Lankreijer et al., 1999). A clear rheological stratification of the lithosphere is visible. The Moldanubicum core of the Bohemian massif indicates a strong keel. The strength rapidly decreases away from the strong center towards SE and NW. The Carpathian foreland is relatively strong, too. The Vienna basin shows a remarkably strong lithosphere owing to the fact we did not correct for the insulation effect of thermal blanketing of the over $6 \mathrm{~km}$ fill of the basin. The Pannonian basin typically only displays lithospheric strength in the uppermost parts of the crust.

and $60 \mathrm{~km}$ (Onescu, 1984). The other earthquakes in the Carpathian-Pannonian region are shallow and their origin is related probably to processes different from subduction.

For about $10 \%$ of the total number of the macroseismically located earthquakes in Slovakia, macroseismic focal depths were determined. They range from several kilometres down to approximately $15-18 \mathrm{~km}$. The focal depth interval is confirmed by seismometric hypocenter locations. The recent study of the 5 June 1443 Central Slovakia earthquake (Labák et al., 1996) shows that the previously reported focal depth of about $25 \mathrm{~km}$ is doubtful and available data do not allow reliable focal depth determination. The Western Carpathians and surrounding region can be, therefore, characterised by shallow crustal earthquakes.

Based on extrapolation of failure criteria, lithology and temperature models, Lankreijer et al. (1999) predicted rheology of the lithosphere for two sections through the Western Carpathians and surrounding regions. Yield-strength contour plot for compressional deformation for NW-SE crosssection of Central Europe from the Bohemian Massif via the Western Carpathians to the Pannonian basin is shown in Fig. 2. The lithological model was defined by means of gravity and geothermal interpretations, together with deep seismic profiling on the structure and composition of the crust and subcrustal lithosphere. They adopted a five-layer lithological model for the calculation of yield strength profiles. 


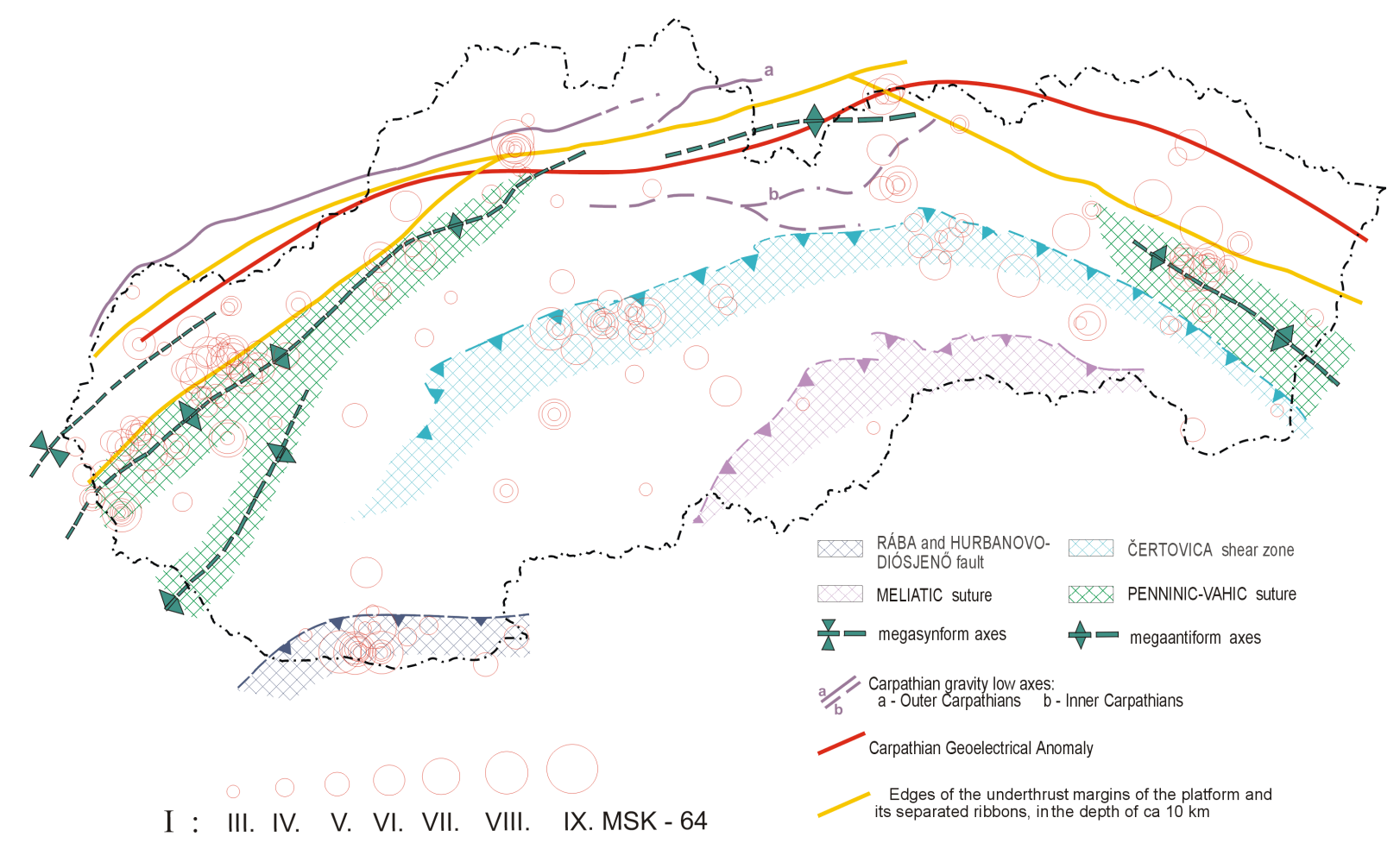

Fig. 3. Map of suture and major shortening zones of the Western Carpathians (Plašienka et al., 1997a) in comparison with the epicenters of macroseimically observed earthquakes on the territory of Slovakia for the period 1034-1990 (Labák and Brouček, 1996). Hachured areas outline depth extent of lower units up to approximately $5 \mathrm{~km}$ below the pre-Tertiary surface.

The model consists of a sedimentary layer, a quartzite layer (representing the sedimentary nappes and volcanic rocks), a granite layer (for the upper crust), a diorite layer (for the lower crust), and a dunite layer representing the lithospheric mantle. The strengths for both brittle and ductile deformation were calculated, with the lesser of these representing the limiting strength (yield strength) of the lithosphere at that particular depth interval (Beekman, 1994). A bulk lithospheric strain rate of $\varepsilon=10^{-15} \mathrm{~s}^{-1}$ and the yield strength of $260 \mathrm{MPa}$ (after Ord and Hobbs, 1989) were used for calculations. The lithospheric strength profiles thus indicate strong and weak rheological layers in the lithosphere.

The rheology predictions (Lankreijer et al., 1999) indicate horizontal rheological stratification of the lithosphere in the foreland of the Western Carpathians. Mechanically strong behaviour is predicted for the upper part of the crust, the uppermost part of the lower crust and the uppermost part of the mantle. The weak lower parts of the upper crust and the lower crust are supposed to be the most obvious detachment levels. The effective elastic thickness (EET) of $13-33 \mathrm{~km}$ was indicated by these strength predictions. The Central Western Carpathians represent a transition zone separating the regions of mechanical strong lithosphere of the European Platform zone and region of extremely mechanical weak lithosphere of the Pannonian Basin. In contrast to the platform units, the lower crustal strength completely disappears here as a result of crustal thickening and increased crustal temperatures. The predicted EET reaches $15-23 \mathrm{~km}$ in the Central Western Carpathians. The Pannonian rheological structure is characterised by one relatively thin strong layer in the uppermost $10 \mathrm{~km}$ of the crust and complete absence of strength in the lower crust and lower lithosphere. The extreme weakness of the lithosphere is a direct result of the high heat flow density and the extremely shallow asthenosphere in the Pannonian Basin. The EET is estimated to 1-10 km (Lankreijer et al., 1999; Bielik et al., 2001).

The distribution of earthquake focal depths (Zsíros et al., 1988; Labák and Brouček, 1996; Schenk et al., 2000) compares very well to the predicted yield envelopes (Lankreijer, 1998). While the Pannonian basin is characterised by shallow earthquakes $(<10 \mathrm{~km})$, the marginal parts of the Western Carpathians and peripheral Pannonian Basin areas by earthquakes at intermediate crustal depths $(<20 \mathrm{~km})$. The distribution of deep seismicity in the Vrancea area still forms one of the key-questions in the Carpathian tectonics.

\section{Combined structural pattern of seismo-tectonic zones}

The seismo-tectonic zones that possibly generate earthquakes in the brittle upper crust of the Western Carpathians are considered here as a combination and joint effect of three levels of crustal inhomogeneities commonly forming weak zones, which were formed during various stages of the geodynamic evolution of the orogen. All three levels are mutually related, tied by multiple reactivation. It is reasonable 


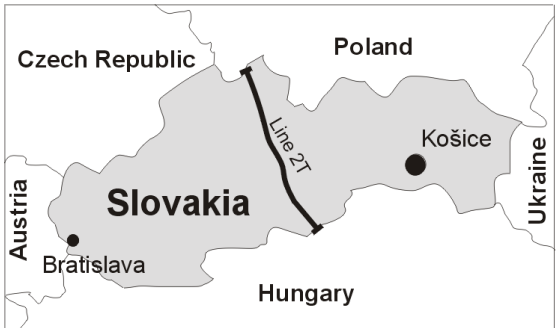

\section{LINE 2T}

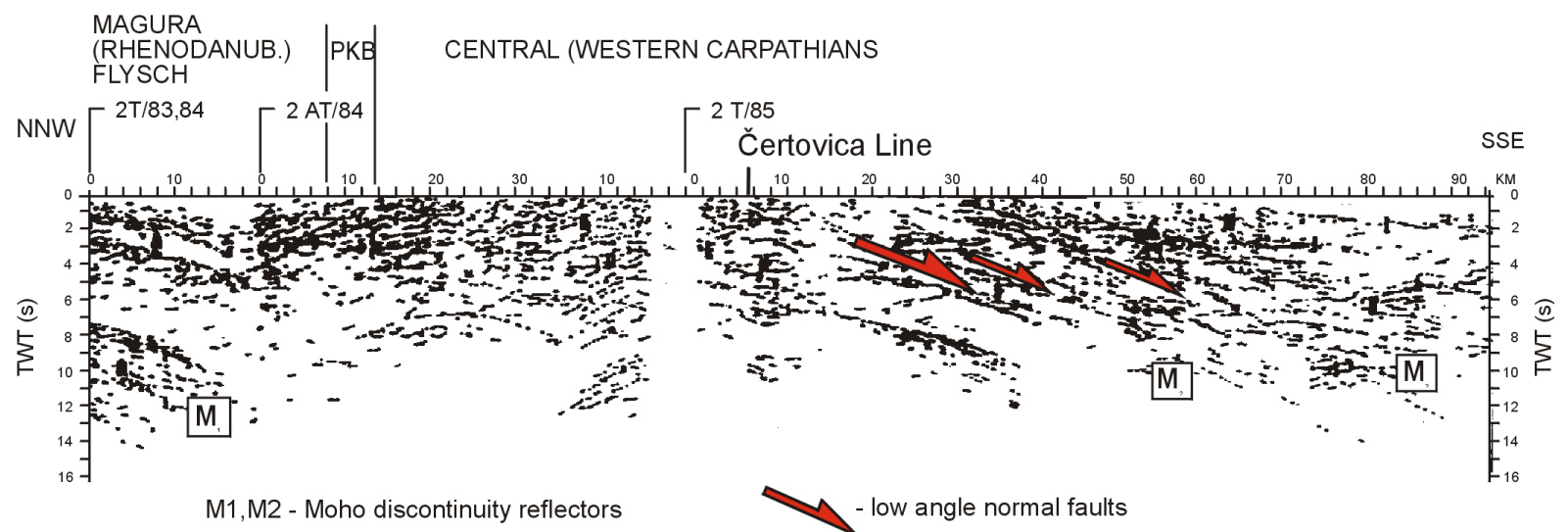

Fig. 4. Line drawing interpretation of the $2 \mathrm{~T}$ seismic time cross-section (Tomek et al., 1989, modified) from the Carpathian Flysch Belt to the Rimava Basin.

to think, that these inherent zones of relatively low brittle strength are the preferential sites of crustal stress release. The deepest level is represented by the Paleo- and Meso-Alpine deep-seated sutures and low-angle, crustal-scale shear zones that originated during the subduction or underthrusting of the oceanic and/or attenuated continental crust. The middle level of the combined multifloor structural pattern is represented by the Neo-Alpine brittle, high-angle, dominantly wrenchtype fault zones. Some of them reach the uppermost parts of the Earth's crust where these fault zones and newly generated shallow faults were activated during the neotectonic period, hence representing the third structural level.

\section{Early Alpine shear zones of the Western Carpathian orogen}

The crustal weakness zones that are interpreted as the zones of extensive shortening of presumably oceanic and/or attenuated continental crust have been identified on the basis of surface geology, reflection seismic and magnetoteluric soundings and paleotectonic reconstructions. In particular, their high conductivity indicates either the presence of ultramylonites, zones with deep-generated fluids, or some other rock masses containing clays and/or black shales. A metamorphic process with graphite coating on mineral grains is not ruled out either. Nevertheless, all these environments should have a decreased coefficient of inner friction.
The suture and shear zones were defined by Plašienka et al. (1997a), the most important of them are (from the north to the south, Fig. 3): the oceanic Penninic-Vahic suture (formed 70-60 Ma before), the intracontinental Čertovica fault zone between the Tatric and Veporic thick-skinned thrust sheets (locked 90 Ma before), the Meliata and related oceanic suture (closed at 120-140 Ma) and the overthrust of Transdanubian units over Austroalpine and Slovakocarpathian units. The courses of the shear zones, or of their parts at least, are followed by earthquakes, mainly in areas that are dissected by younger fault systems at the surface.

(a) The Penninic-Vahic suture zone principally represents the boundary between the Outer and Central Western Carpathians. In the north, it is limited by the Pieniny Klippen Belt. This zone consists of several sectors: the western follows the seismoactive Váh river valley as far as Žilina, the central part is relatively quiet and the eastern seismoactive part occupies a broader area of the East Slovakian Basin.

(b) The Čertovica shear zone represents an intracontinentaltype suture between the Tatric and Veporic basement sheets. Along the 2T deep seismic profile, some zones of very low resistivities are observable in the deeper parts (Fig. 4), besides the distinct reflection bunches inclined to the SE (Tomek et al., 1989). The high reflectance may, however, indicate probable extensional 
$\stackrel{\varrho}{\varrho}$ हैं

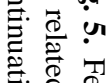

$\frac{1}{0} \frac{0}{0}$

$\omega-$.

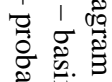

苛

릉

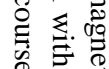

0 용요

它

궁

宾豆

용

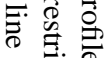

纪

远

कै त्व

8 苋

․

를 을

훙

$1 \stackrel{0}{=}$

8 运

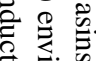

․․ㄹ.

월

宅总

$\sim \mathrm{G}$.

1

응

호류.

옹

产 용

$\stackrel{1}{\circ}$

귱.

룽 \&

+ 은

1 . 융

क

$\overrightarrow{0}$ :

年

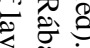

离

危

摸

व

离

\%

政

ह.

.

䆙

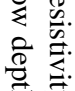

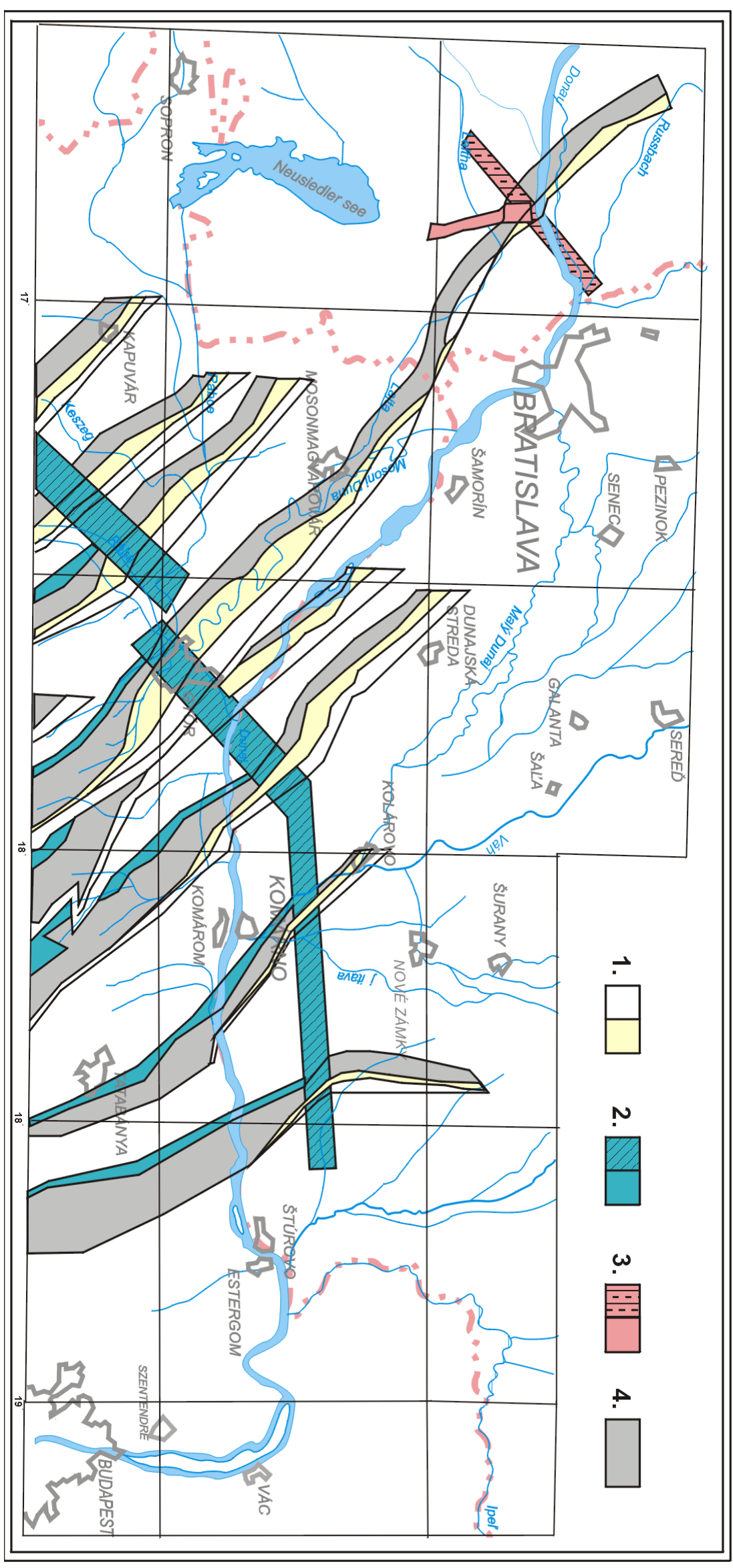



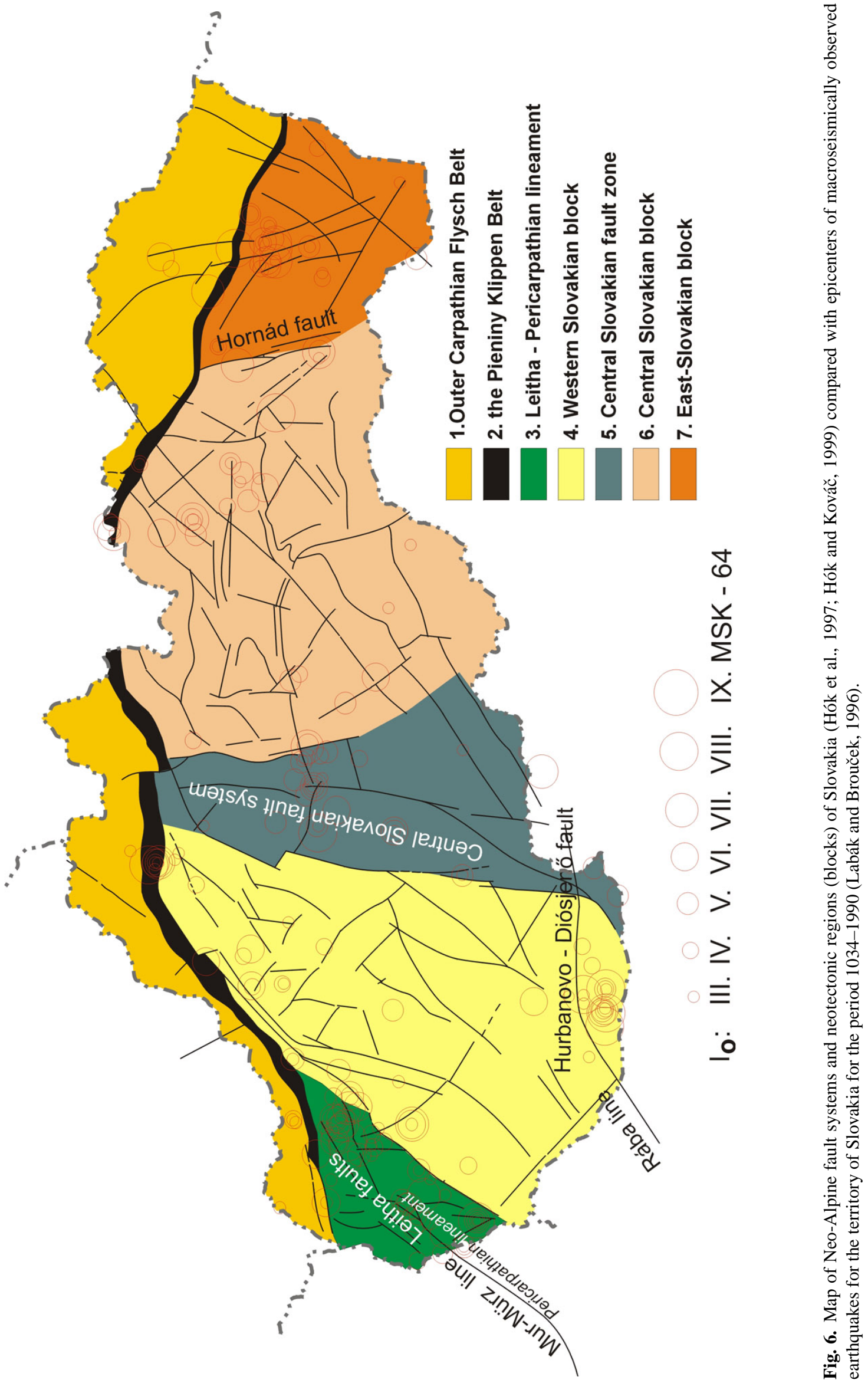
reactivation of the overthrust, which generates seismic events on the crossing of the Paleo-Alpine overthrust with younger brittle faults.

(c) The Meliata oceanic suture zone occurs at the southern margin of the Central Western Carpathians. It is steeply inclined towards the SE, is relatively poorly known and seems to be seismically inactive.

(d) The surficial expression of the contact between the Austroalpine (Slovakocarpathian) units and the Transdanubian Range units (with South Alpine affinities - Haas et al., 1995) is the Rába and the Hurbanovo-Diósjenó fault zones. The ENE-WSW running Hurbanovo-Diósjenó fault system is related to the earthquakes mainly at its crossing with smaller transverse brittle fault structures.

It is important to note, that the whole tectonic body of the Transdanubian Range is underlain by the zones of very low resistivity at 5 to $20 \mathrm{~km}$ depths (Fig. 5, after Nemesi et al., 1997). Seemingly, they represent originally incompetent shear zone and the Transdanubian Range represents an upper thrust unit (Tari, 1996).

\section{Neo-Alpine brittle fault zones}

The Neo-Alpine evolution of the Western Carpathians is related to an oblique collision with the European Platform and subsequent extrusion of litospheric segments (belonging to the ALCAPA megaunit) from the East Alpine collision area (e.g. Ratschbacher et al., 1991a, b; Csontos et al., 1992). The whole process was associated with compression and generation of diachronous overthrust of nappes in front of the orogen (Jiřriček, 1979), rotation of crustal segments of the internides (cf. Csontos, 1995; Kováč and Márton, 1998) and continuous change from transpression, transtension to extension in the orogen hinterland (cf. Kováč and Baráth, 1995). The back-arc basin formation on the overriding plate and subduction of the slab below the Outer Carpathian flysch troughs was associated with voluminous acid and intermediate calc-alkaline volcanism (Lexa et al., 1993; Royden, 1993a, b).

During the Neogene, the orientation of the stress field was influenced by the geodynamic position of the rotating Western Carpathian internides (e.g. Márton and Fodor, 1995; Kováč et al., 1997a, b; Nemčok et al., 1998). The recent paleostress fields measurements document NW-SE oriented compression for the Early Miocene, and NE-SW compression for the Middle Miocene with NW-SE oriented extension in the western and NE-SW oriented extension in the eastern part of the orogenic hinterland (Kováč et al., 1997b). From the Pliocene onward, the compression was oriented almost identically with the recent stress field (Bada, 1999).

In agreement with paleostress field data, the basin development shows several tectonic-sedimentary megacycles, where the beginning of the last one corresponds to the Miocene/Pliocene boundary (Kováč and Baráth, 1995;
Kováč et al., 1997a). We consider the beginning of this last megacycle, starting at the end of Miocene, as the neotectonic period, which represents the last stage of the development of the Western Carpathian combined structural pattern.

\subsection{Principal fault systems on the territory of Slovakia}

Map of fault systems with verified Neo-Alpine activity (Fig. 6) is based on data about the orientation of paleostress fields, geotectonic position, character of sedimentation, as well as it is based on the geological and geophysical criteria. The names of the individual faults were given by several authors (e.g. Hók et al., 1997). During the compilation of the map we used mainly structural-geological map of Czechoslovakia (based on remote-sensing interpretations in the scale 1:500 000 - Reichwalder, 1984), geological map of Slovakia 1:500 000 (Biely ed., 1996), map of the pre-Tertiary basement of the Central and Inner Western Carpathians (Fusán et al., 1987) and regional geologic maps of Slovakia in the scale 1:50 000. The map contains also data and facts from works by Marko (1986), Mahel' (1986), Csontos et al. (1991, 1992) and Maglay et al. (1993).

Among the mentioned fault systems the wrench zones are of special importance for the Neogene evolution of the Western Carpathians. The most important of them leaves the Eastern Alps (Mur-Mürz line), which continues as the Pericarpathian lineament (Leitha faults) northeastward. This fault zone represents the boundary between units of the Eastern Alps and the Western Carpathians.

Two further fault system strongly affecting the Central Western Carpathians are the Central Slovakian fault system (Kováč and Hók, 1993) and the Eastern Slovakian Hornád fault system representing from the geophysical point of view a transition from the Western Carpathian crustal structures into the Eastern Carpathian ones. Both fault systems are associated with voluminous Neogene volcanism.

(1) The Pericarpathian fault system - Leitha faults. Along the 3T seismic profile crossing the Vienna Basin, Malé Karpaty Mts. and the Danube Basin, deep-seated zones of very low resistivity were sporadically registered by MTS method (Varga and Lada, 1988). The first one, seismically reflected as a flower-structure, occurs in the vicinity of Schrattenberg fault at the western margin of the basin (Červ et al., 1994); the second zone of very low resistivity was recorded in the SE part of the Vienna Basin (in the SE continuation of the Malé Karpaty Mts. to Austria). Similarly as the first zone it is represented by a seismically identified flower-structure along the $8 \mathrm{HR}$ and $3 \mathrm{~T}$ reflection seismic profiles (Tomek and Thon, 1988) close to the Malé Karpaty Mts. (Fig. 7) Based on the coincidence of the mentioned phenomena, as well as on the knowledge of the pull-apart opening of the Vienna Basin during the extrusion of the West Carpathian lithospheric fragment from the Alpine collision zone in the Early Miocene (Royden, 1988; Csontos et al., 1992; Kováč et al., 1993; Fodor, 1995), the 


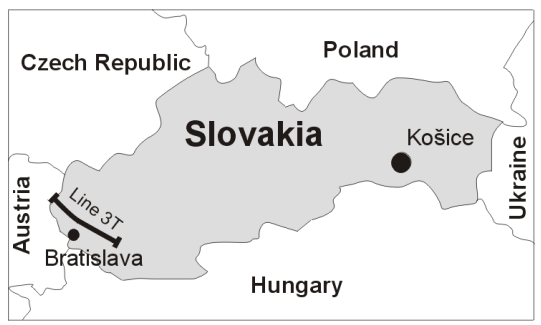

\section{LINE 3T}

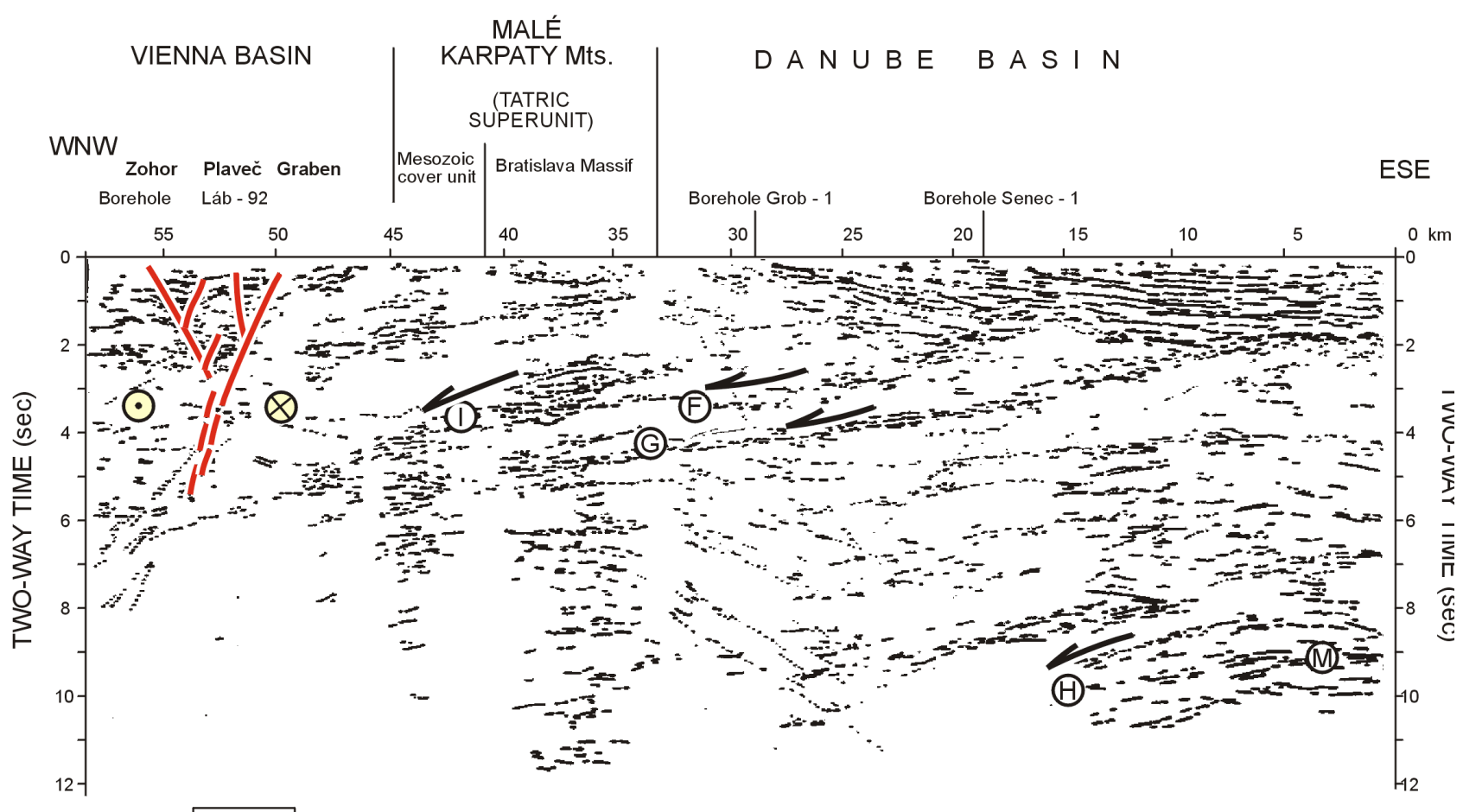

$O \otimes 1$.

Fig. 7. Line drawing of the $3 \mathrm{~T}$ seismic time cross-section (Tomek and Thon, 1988, modified). F, G, I - normal faults, M - MOHO, H extension in the lower crust. 1 - sinistral wrench zone.

low-resistivity zones can be reasonably considered as first-order, crustal-scale shear zones. The activity of Leitha faults from the Neogene up to the Quaternary, besides the seismic data (Gutdeutsch and Aric, 1987, 1988), is well documented also by the young Quaternary structure of the Zohor-Plavecký Štvrtok graben situated above the Leitha faults (Fig. 7).

(2) The Central Slovakian fault system (CSFS) forms an approximately $20-25 \mathrm{~km}$ wide, $\mathrm{N}-\mathrm{S}$ trending fault zone (Fig. 6). However, the tectonic character of the CSFS is different from the Pericarpathian lineament mentioned above. Firstly, it does not represent a boundary between different geotectonic units, and secondly, it is situated within the Western Carpathian internides (sensu Mišík et al., 1985). From the tectonic point of view, it is a transtensional fault zone active since the Neogene. Interpretation of the geophysical data reveals that the western border of the CSFS between the Turiec Basin situated above the northern part of the CSFS and the Hurbanovo-Diósjenô line reaches the MOHO discontinuity, and the other faults of the CSFS reach lower parts of the crust (Kvitkovič and Plančár, 1977). Depending on the changing paleostress field, the CSFS can be characterised as a dextral (in the Early Miocene) and later as a sinistral transtensional fault zone with predominance of oblique horizontal movements of small amplitude. The activity of the CSFS influenced the spatial distribution of the Neogene and Quaternary volcanic centres in Central Slovakia (Štohl, 1976; Kováč and Baráth, 1995; Kováč et al., 1997b; Šimon and Halouzka, 1996). Currently the CSFS separates areas with subsiding tendencies of crust in the west from stabilised areas in the east (Figs. 6 and 10). Furthermore, these blocks differ also in crustal thickness, heat-flow intensity and distribution of Neogene and Quaternary sediments. 
(3) The Hornád fault system (HFS) represents the eastern boundary of the uplifted Central Western Carpathians against the subsiding East Slovakian Basin. Similarly to the CSFS, the faults represent a transtensional zone with oblique-slip horizontal movements of minor amplitude during the Neogene. Additionally, the Miocene volcanic centres of the Slanské vrchy Mts. are bounded to this fault zone. Comparison between locations of the fault structures and earthquake hypocentres (Fig. 6) documents only a weak seismic activity along the HFS. However, the neighbouring parallel Ondava and Laborec faults situated within the East Slovakian Neogene Basin, above the subsurface elevation of the Penninictype Iňačovce-Krichevo Zone (Soták et al., 1994; Bielik et al., 1998), seem to be seismically much more active (Fig. 3).

\section{Neotectonic fault activity}

The term neotectonics for the territory of Slovakia and the Western Carpathians was defined by Hrašna (1998) as ongoing tectonic events and processes, which started in postMiocene times. The neotectonic period corresponds approximately to the last $5.4 \mathrm{Ma}$ and is characterised by a stress field with similar characteristics to the present one.

\subsection{Contemporary stress field}

The orientation and size of the present stress field in the Western Carpathians is determined by the main stress sources in the whole Alpine-Carpathian-Pannonian-Dinaric system. Based on the Bada's finite element model calculations (1999), the first-order source (several tens to hundreds MPa for the EET of about $10 \mathrm{~km}$ ) is the counterclockwise rotation of the Adriatic microplate ("Adriatic push"). Its Euler-pole of rotation is located at the coordinates $46^{\circ} \mathrm{N}, 6^{\circ} \mathrm{E}$. Sources of second-order stresses come from the convergence and compression in the Vrancea area (perpendicular to the Eastern Carpathian arc) and slight compression generated by the Bohemian Massif (perpendicular to the boundary of the Bohemian Massif with the Western Carpathians). The Moesian Platform is supposed to be stable (Bada, 1999). In addition, the recent stress field is relatively weakly influenced by variability EET of the lithosphere. Even the topography-related sources can have a local significance.

We attempt to establish recent stress field in the Western Carpathians mainly on the basis of published works (e.g. Gerner, 1992; Zoback, 1992; Müller et al., 1992; Gerner et al., 1995; Horváth and Cloetingh, 1996; Gölke and Coblentz, 1996; Peresson and Decker, 1996; Bada, 1999), from available, though scarce focal mechanism data (Pospíšil et al., 1992; Labák et al., 1997; Jarosiński, 1997) and from data of our own geological and structural analyses (Hók et al., 1995, 1997, 1998).

The presented map (Fig. 8) shows a compilation of the actual stage of knowledge with a minimum amount of correc- tion of the results. It is comparable to the works of Horváth and Cloetingh (1996) and Bada (1999). The main compression axis is oriented perpendicularly to the Carpathian arc in the area of the Outer Carpathians and Vienna Basin (Jarosiński, 1997; Bada, 1999). We explain this as an effect of continuing convergence of the stable European Platform and the Western Carpathian block. Orientation of the compressional component of the recent stress field varies between W-E to NW-SE in the western part of the orogen, up to N-S in eastern Slovakia.

We can characterise the central parts of the Western Carpathians on the basis of only one existing data of earthquake focal mechanism (next to Banská Bystrica; Fig. 9). The stress field determines a sinistral oblique-slip with extension oriented NW-SE (Pospíšil et al., 1992). We correlate this regime with an extensional reactivation of a thrust plane between the Veporic and Tatric units (cf. Hók et al., 1997; Šefara et al., 1998). Projection of this thrust plane to the surface coincides with the Čertovica line. This idea is in a good agreement with data on the crustal thickness in Central Slovakia (e.g. Horváth, 1993; Šefara et al., 1996), geophysical interpretations (e.g. Bezák et al., 1993, 1995, 1998; Šefara et al., 1998), as well as with data on recent vertical movement (Vanko, 1988; Joó, 1992).

It is possible to correlate these data with the extensional tectonic regime that causes faulting of the Pliocene deposits in the eastern to north-eastern part of the Danube Basin. In the north-western part of the Danube Basin (Blatné and Rišňovce Depressions), the orientation of extension was derived from tectonic deformations of Pliocene sequences, geomorphological interpretations (Stankoviansky, 1993, 1994) and earthquake focal mechanism (Labák et al., 1997). Extension is oriented in the NE-SW direction.

We cannot explain the youngest changes in the stress field orientation in the area of the Danube Basin satisfactorily, because of shortage of exact data about the character, age and distribution of the Upper Miocene, Pliocene and Pleistocene, tectonically deformed sediments and an absence of stress data and earthquake focal mechanisms and recent "in situ" stress measurements. There is a possibility that the stress field changes are influenced by the extensional reactivation of the Čertovica line, which is assumed to continue in this area of the Danube Basin basement.

Another important assumption for the changes of the stress regime is the reorientation of the main stress components from the zone of continuing convergence in the Outer Carpathians with a dominant thrust faulting character, through wrench zones (strike-slip faults) immediately behind the area of convergence (e.g. transpression in the Pieniny Klippen Belt), transtension in the area of Central Slovakian fault system, up to extension and ongoing subsidence in the central part of Danube Basin (Figs. 8, 9). This spatial change is most clearly pronounced in Western Slovakia where it is documented by focal mechanisms derived from earthquakes in the Vienna Basin, Dobrá Voda Depression and NW border of the Danube Basin (Blatné Depression). 

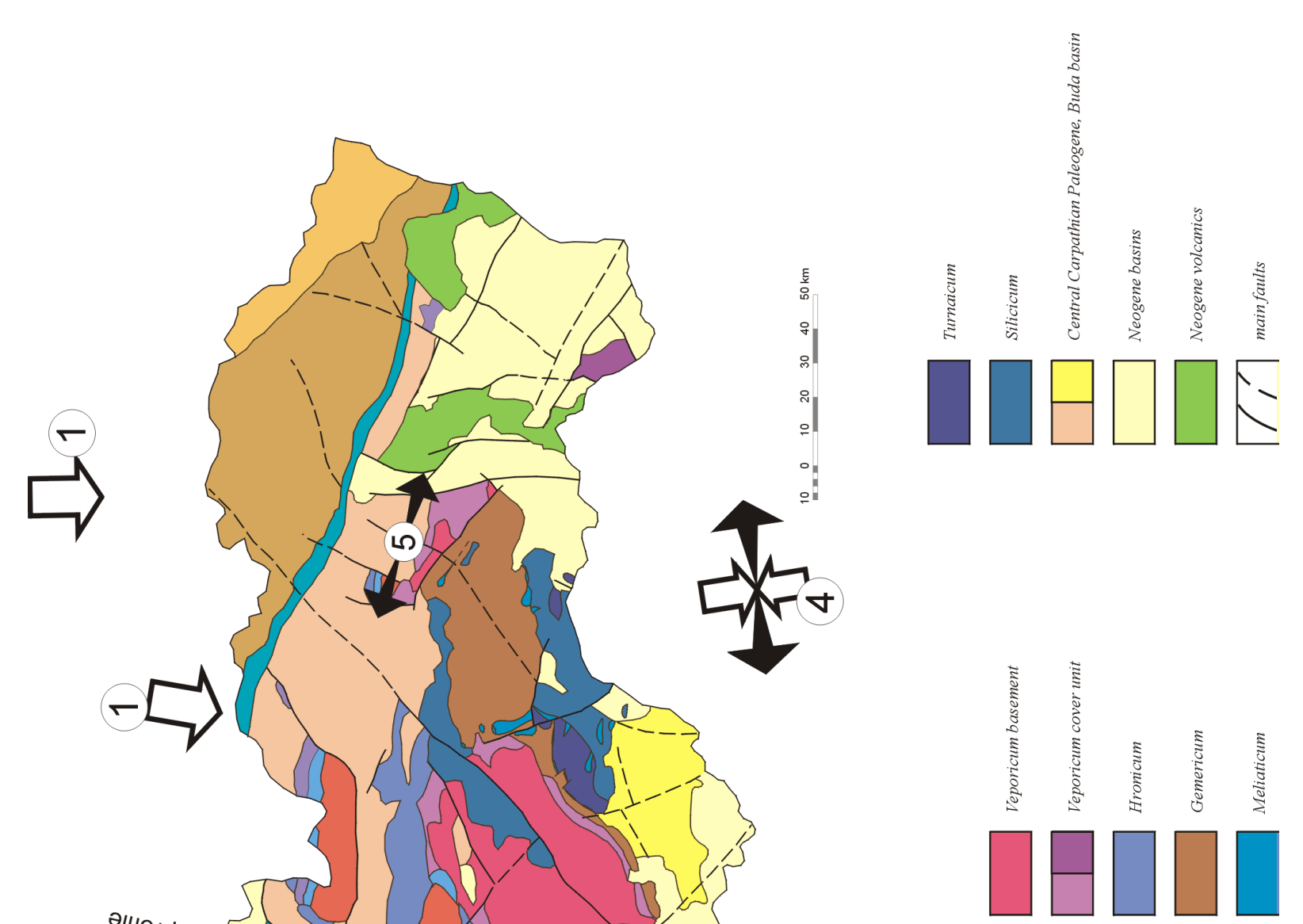

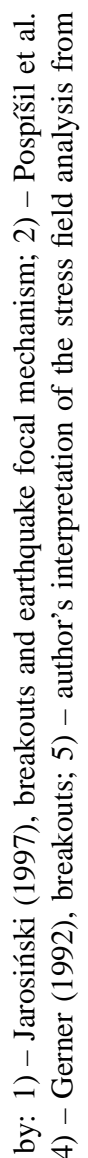
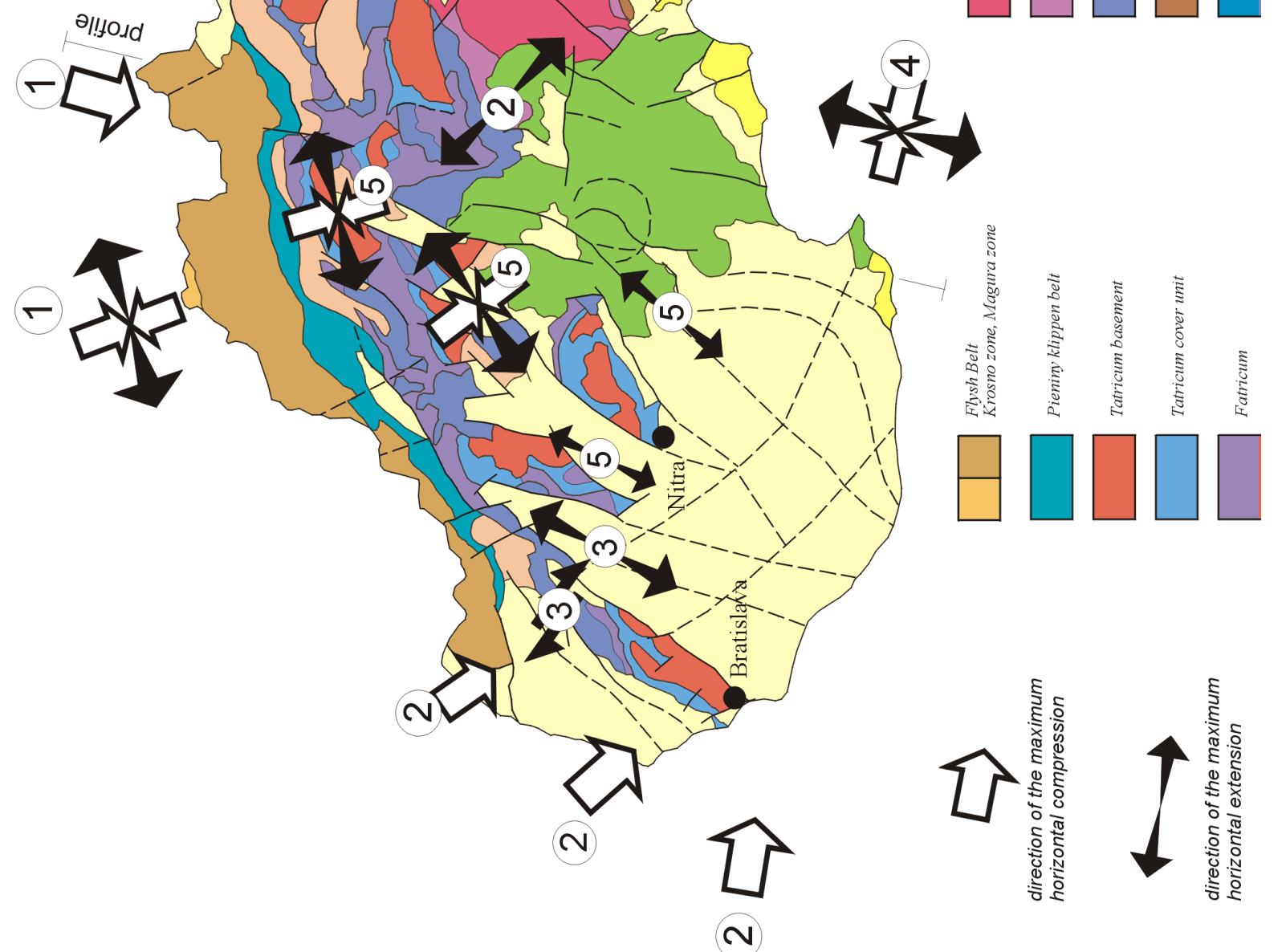

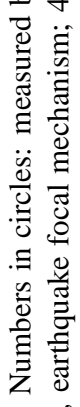

官客离

तें

落

$\frac{\pi}{9} 1$

ส

음

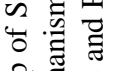

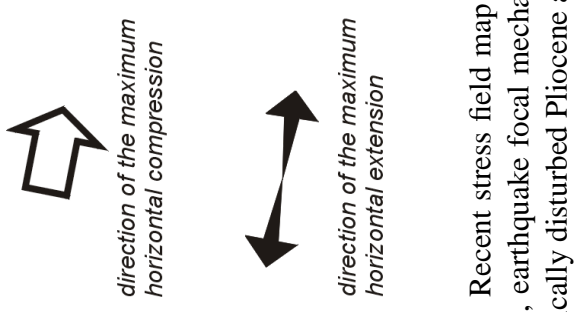

$\infty \dot{\widehat{\sigma}} \cdot \ddot{\Xi}$

ํํㅊ 


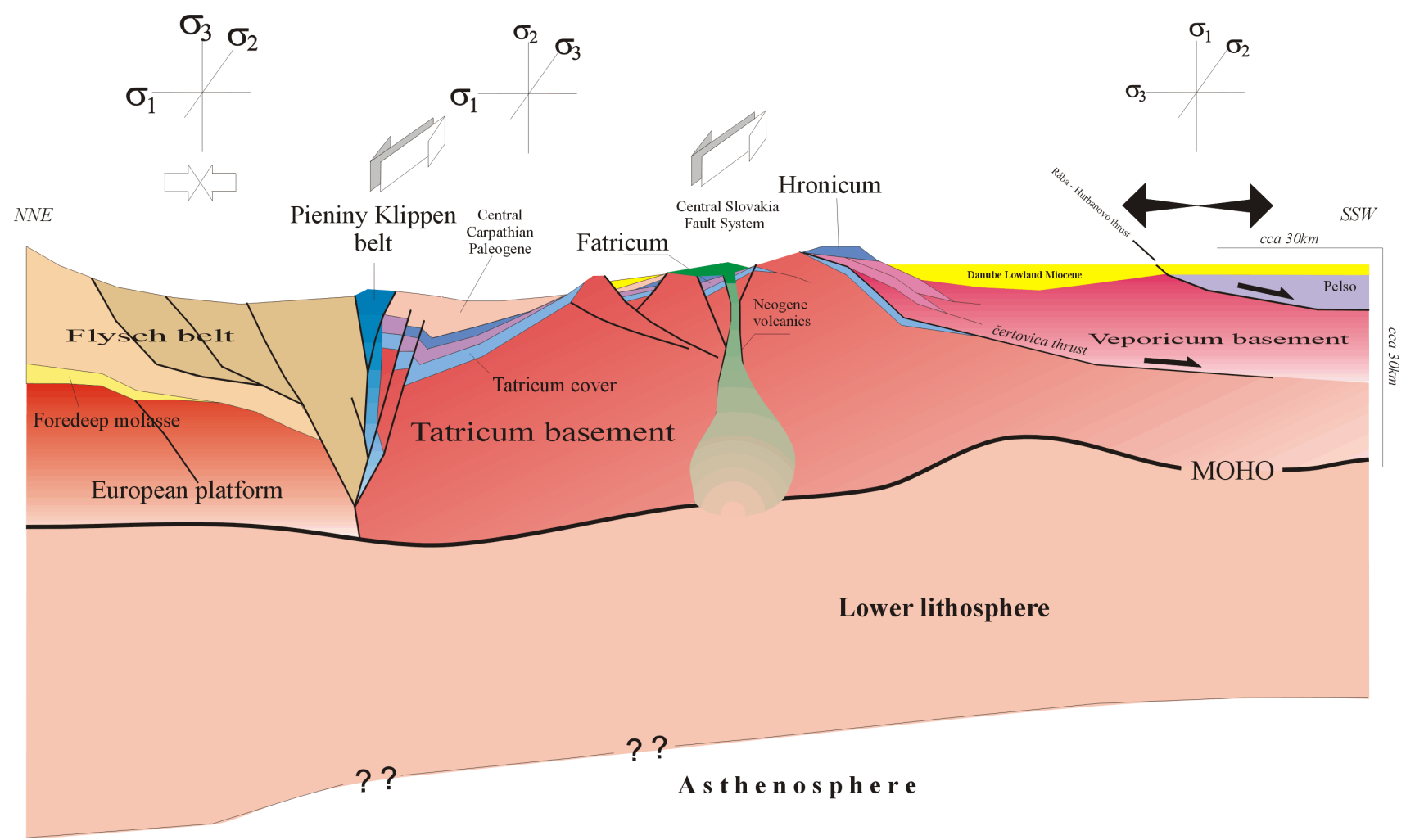

Fig. 9. Idealised tectonic cross-section through the Western Carpathians and dominant tectonic regimes (Hók et al., 1999).

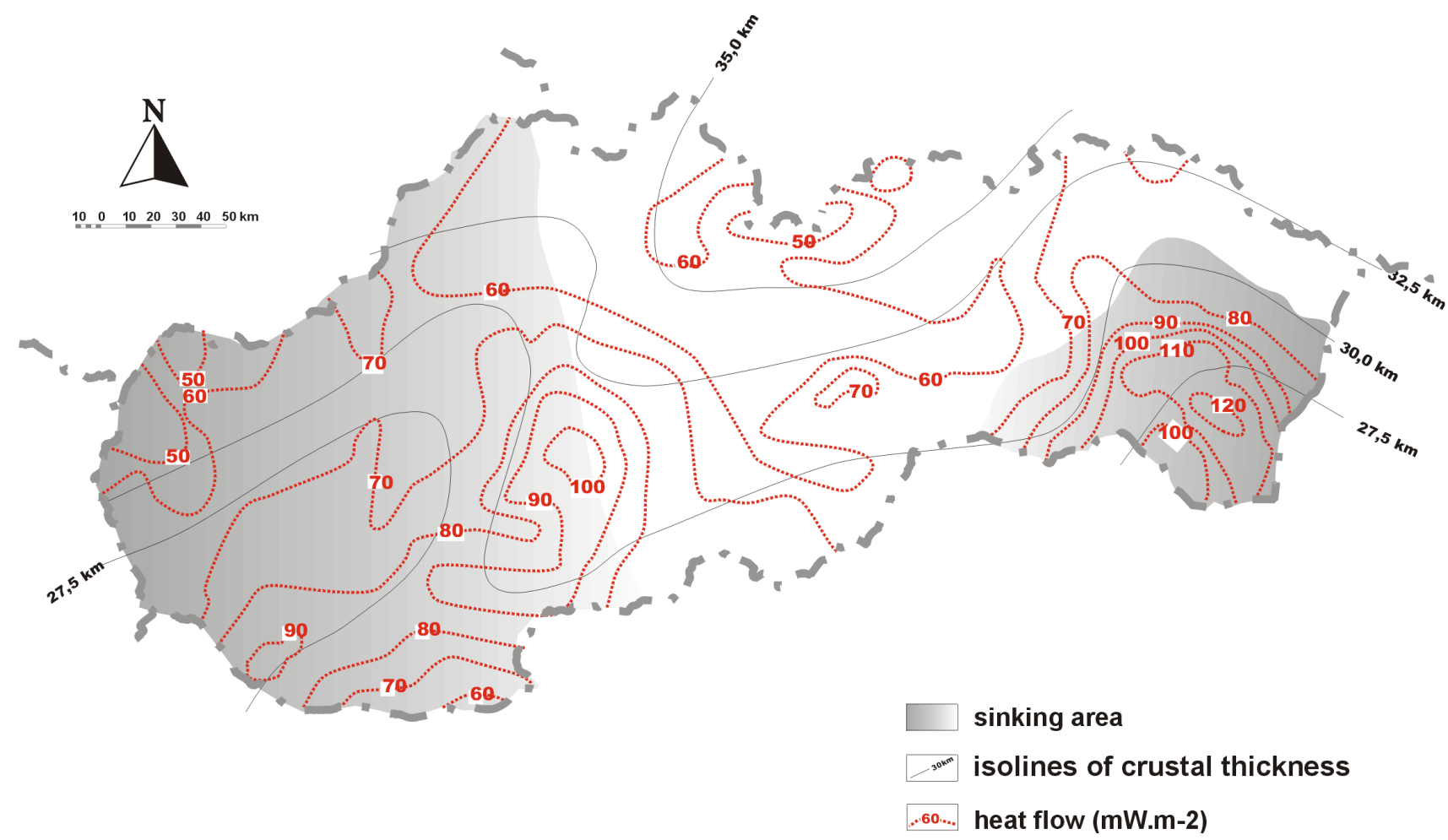

Fig. 10. Vertical movement tendecies of Slovakia (after Vanko, 1988 and Joó, 1992) in comparison to crustal thickness (after Horváth, 1993 and Šefara et al., 1996) and heat - flow values (after Franko et al., 1995). 


\subsection{Recent vertical movement tendencies}

For a compilation of the map of recent vertical movements (Fig. 10) we used results acquired by geodetic methods during the last decades. We mainly based our study on the works by Kvitkovič and Plančár (1975, 1977), Marčák et al. (1976), Vanko and Kvitkovič (1980), Vanko and Vyskočil (1987), Vanko (1988), Kvitkovič and Vanko (1990) and Joó (1992). During the compilation we also took into account the work of Kvitkovič (1993) who definitely excluded the previously assumed possibility of positive movement tendencies of the area of the Gabčíkovo Depression, because of thick accumulations of Quaternary sediments there (more than $400 \mathrm{~m}$ ). The constructed map of recent vertical movement tendencies of Slovakia depicts the most lately published isolines of vertical movements (Vanko, 1988; Joó, 1992), isolines of crustal thickness deduced from maps of Horváth (1993) and Šefara et al. (1996) and isolines of heat-flow density (Franko et al., 1995). The map enables to recognise clearly the close correspondence of crustal thickness and vertical movement tendencies. Maximum values of heat-flow in the Danube Basin (Milička et al., 1994, 1996) are partly shifted towards the area of the Central Slovakian neovolcanics where they are interpreted to be related to the residual volcanic heat flow. The central part of Slovakia shows weak uplift tendencies in contrast to relative subsidence of its western and eastern parts (Fig. 10).

The rising tendency of the Outer Western Carpathians and especially their foreland can be related to a flexural bulge of the European Plate loaded by the flysch nappes and the Central Western Carpathian units (Karner and Watts, 1983; Royden, 1993a, b; Bielik, 1995, 1998; Krzywiec and Jochym, 1997; Zoetemeijer et al., 1999). Recent uplift tendencies in the area of the Flysch Belt, documented also by its significant erosion, were quantified in the work of Zoetemeijer et al. (1999). The total post-collision rise of the European foreland varies from about $300 \mathrm{~m}$ near Brno, $450 \mathrm{~m}$ in the Rhenohercynian units east of the Bohemian Massif up to 225-300 $\mathrm{m}$ in the area of the Flysch Belt of the Outer Western Carpathians.

\section{Discussion and conclusions}

In most cases the seismic events are related to movements along the fault surfaces. Therefore it is possible to correlate earthquake hypocentres with the fault structures, which are from the genetic point of view of seismic events in an appropriate angular relationship with the principal stress axes. Based on the geological structure, tectonic deformation, localised earthquake epicentres and geophysical characteristics, we have tried to identify geological structures, which, in our opinion, could generate seismic events (Fig. 11).

The most remarkable and important, first-order tectonic structure in the Western Carpathians is the zone of the Pieniny Klippen Belt (Fig. 11) in the wider surroundings of the Dobrá Voda depression coinciding with the Mur-MürzLeitha Line or with the Pericarpathian fault on the NW mar- gin of the Malé Karpaty Mts. The Pieniny Klippen Belt represents a topographic contact of the block of the Central Western Carpathians and the stable European Platform. The Mur-Mürz-Leitha line in the area of the Vienna Basin represents topographical dissection of contact of the Eastern Alps units with the Western Carpathians (Vozár et al., 1998). Both these tectonic lines represent subvertical boundaries with a probable Tertiary tectonic activity (e.g. Ratschbacher et al., 1991a, b; Kováč and Hók, 1996; Kováč et al., 1997a). In our opinion the increased seismic activity in the Dobrá Voda Depression is a result of merging of the above discussed two tectonic lines, since an existence of the NW-SE oriented "Dobrá Voda Fault", supposed by Fusán et al. (1987), has not been proved (cf. Marko et al., 1991, 1995; Marko and Kováč, 1996). We consider the earthquakes with epicentres concentrated mainly in the area E and SE of cities Banská Bystrica and Brezno to be related to the Čertovica line (Fig. 11). The Certovica line is a surface projection of the thrust plane of the Veporic basement sheet over the Tatricum. Based on geological data, earthquake focal mechanisms (Pospíšil et al., 1992), geophysical data (Bezák et al., 1993, 1995; Šefara et al., 1998) and structural analyses (Hók et al., 1997, 1999, 2000) we consider this sector of the Črtovica Line as a recently active due to extensional collapse of the orogene. Earthquake events are released mostly on the Hron fault system of ENEWSW direction (Fig. 11). It is noteworthy that this system, like the Dobrá Voda system, is distinctive in the recent morphology and can be well traced by remote sensing methods (Janků et al., 1984). This SE-inclined source zone can be also related to the earthquake events released on the N-S trending brittle fault deformations surrounding the Turiec Basin (with less data, Hók et al., 1998), as well as along the continuation of these faults to the Central Carpathian Neogene volcanic area.

A third important geological structure is the HurbanovoDiósjenô fault zone (Fig. 11), which is most probably the continuation of the Rába line (sensu Szafián, 1999) on the Slovakian territory. The Rába line in Hungary is of NE-SW orientation. Based on reflection seismic interpretations (Tari, 1994), there are several low-angle displacement surfaces dipping to the SE in the basement of the Hungarian part of the Danube Basin. Therefore the Rába line cannot be interpreted as a "megatectonic" wrench line and we agree with Szafián (1999) to call it Rába overthrust, which separates the Austroalpine nappes in the NW and units of the Transdanubian Range in the SE. In the territory of Slovakia, this line continues as the mentioned Hurbanovo-Diósjenó line of E-W to ENE-WSW orientation, which also represents a surface projection of the original thrust planes of the Transdanubian units. These thrust planes were reactivated during the Miocene as low-angle extensional faults dipping to the SE (Tari et al., 1992; Horváth, 1993; Haas et al., 1995; Nemesi et al., 1997; Szafián, 1999). The seismic events are generated along these low-angle surfaces and are only indirectly related to the subvertically dipping boundaries (Šefara et al., 1998; Dudko et al., 1990). These assumptions were proved by several industrial, as well as deep seismic profiles cor- 

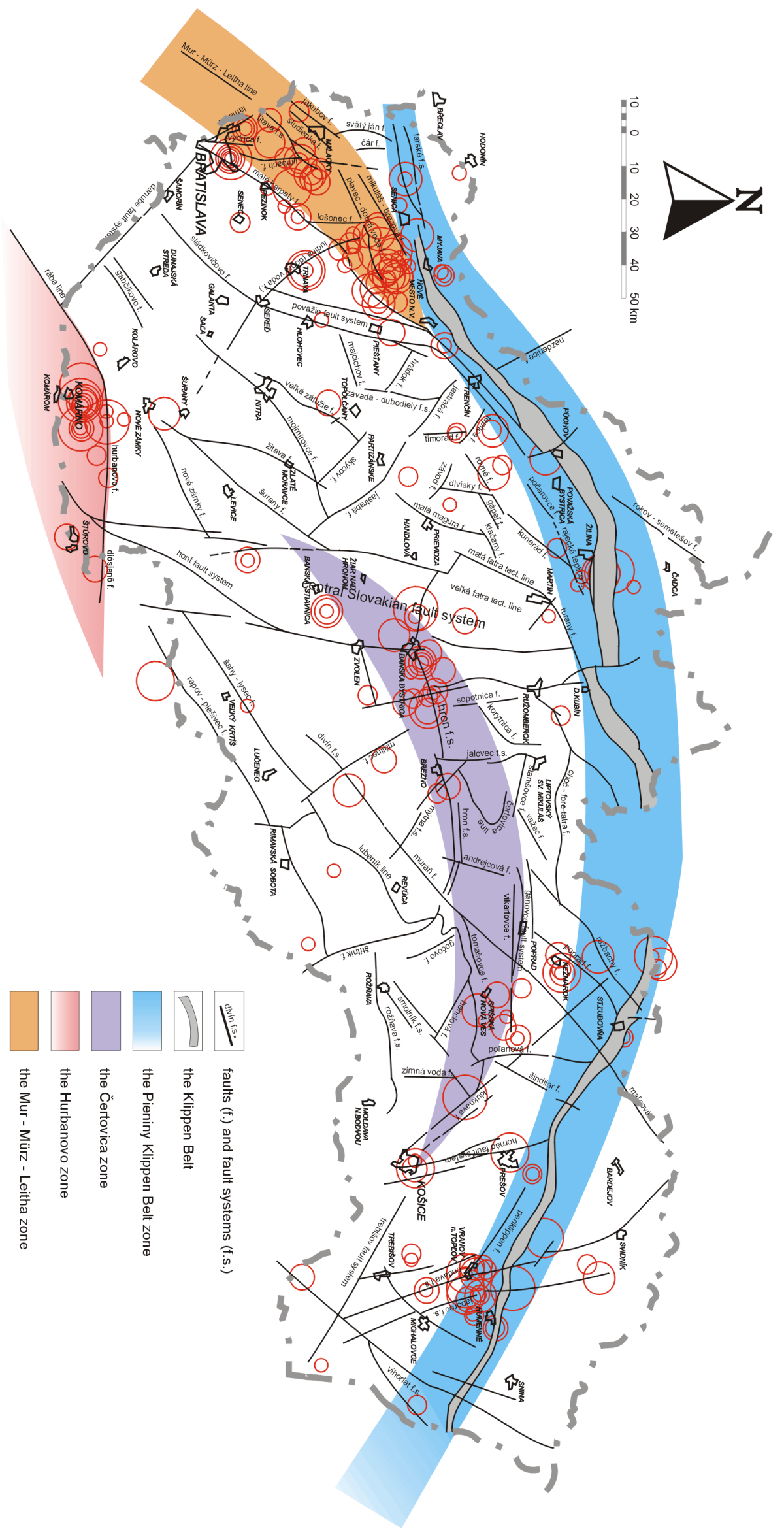
related with drillings (Tari, 1994, 1996) and with density modelling (Szafián, 1999), which presumed the formation of the Danube Basin to be primarily controlled by a system of low-angle normal faults. The Rába line (overthrust) is neotectonically reactivated as a fault system which sole out in the lower crust. Such interpretation is corroborated by results of Ratschbacher et al. (1990, 1991a, b), Horváth (1993), Lankreijer et al. (1997, 1999) and Lankreijer (1998) who proposed that the rheology of the lower crust in the Pannonian region is significantly different from that of the upper crust and is characterised by ductile shear deformation. The location of the low-angle normal faults seems to be largely controlled by the presence of Cretaceous thrust planes, since normal faults affecting the Middle Miocene syn-rift strata of the Danube Basin filing usually merge with older compressional detachment planes at mid-crustal depths.

Acknowledgements. The authors are indebted to Dr. László Csontos (Budapest) and Prof. Ferenc Horváth (Budapest) who provided a valuable review, which substantially improved the paper. This work was supported by Slovak Grant Agency, grant VEGA (projects No. $1137,7060,7068,7087,7215,1091$ ) and by project of Slovak Ministry of Environment VTP 130.

\section{References}

Bada, G.: Cenozoic stress field evolution in the Pannonian Basin and surrounding orogens. NSSG publication No. 990101, Amsterdam, 1-187, 1999.

Beekman, F.: Tectonic modelling of thick-skinned compressional intraplate deformation. NSSG publication No. 940101, Amsterdam, 1-152, 1994.

Bezák, V., Hók, J., Kováč, P. and Madarás, J.: Possibilities of tectonic interpretation of the seismic section 2T (in Slovak, English abstract), in: Rakús, M. and Vozár, J. (Eds.): Geodynamic model and deep structure of the western Carpathians. Konf., Symp., Sem., GÚDŠ, Bratislava, 287-290, 1993.

Bezák, V., Šefara, J., Bielik, M., and Kubeš, P.: Lithospheric structure in the Western Carpathians: geophysical and geological interpretation (in Slovak, English summary). Mineralia Slovaca, 27, 169-178, 1995.

Bezák, V., Šefara, J., Bielik, M. and Kubeš, P.: Models of the Western Carpathian lithosphere, in: Grecula, P., Hovorka, D. and Putiš, M. (Eds.): Geological evolution of the Western Carpathians. Mineralia Slovaca Monograph, Bratislava, 25-34, 1998.

Bielik, M.: Continental convergence in the area of the Western Carpathians on the basis of density modelling. Geologica Carpathica, 46, 3-12, 1995.

Bielik, M.: Analysis of the gravity field in the Western and Eastern Carpathian junction area: density modelling. Geologica Carpathica, 49, 75-83, 1998.

Bielik, M., Šefara, J., Soták, J., Bezák, V., and Kubeš, P.: Deep structure of the Western and Eastern Carpathian junction, in: Rakús, M. (Ed.): Geodynamic development of the Western Carpathians. Geol. Surv. Slov. Rep., D. Štúr Publ., Bratislava, 259-271, 1998.

Bielik, M., Lankreijer, A., and Zoetemeijer, R.: Using of gravity and geothermal fields to rheological study in the Western Carpathians and the surrounding tectonic units. Österreichische Beiträge zu Meteorologie und Geophysik, 26, 47-59, 2001.
Biely, A. (Ed.): Geological map of Slovakia 1:500 000. Geol. Surv. Slov. Rep., Bratislava, 1996.

Brouček, I., Eisinger, U., Farkas, V., Gutdeutsch, R., Hammerl, C., and Szeidovitz, G.: Reconstruction of building damages caused by 1763 earthquake in Komárno/Danube from contemporary depictions of the same site and from respective texts. Proceedings of the ESC XXII General Assembly, Barcelona, 353-360, 1991.

Csontos, L.: Tertiary tectonic evolution of the Intra-Carpathian area: a review. Acta Vulcanologica, 7, 1-13, 1995.

Csontos, L., Tari, G., Bergerat, F., and Fodor, L.: Evolution of the stress fields in the Carpatho-Pannonian area during the Neogene. Tectonophysics, 199, 73-91, 1991.

Csontos, L., Nagymarosy, A., Horváth, F., and Kováč, M.: Tertiary evolution of the Intra-Carpathian area: a model. Tectonophysics, 208, 221-241, 1992.

Červ, V., Pek, J., Pícha, B., Praus, O., and Tobyášová, M.: Magnetotelluric models of inhomogeneity zones, in: Bucha, V. and Blížkovský, M. (Eds): Crustal structure of the Bohemian Massif and the West Carpathians. Academia, Praha, and SpringerVerlag, Heidelberg, 147-157, 1994.

Dudko, A., Balla, Z., and Kövesi, G.: The Rába line and interpretation of gravity anomalies along reflection seismic profile MK1 (in Hungarian with English summary). Annu. Rep. Eötvös L. Geophys. Inst. Hung. 1988-89, 19-47, 1990.

Fodor, L.: From transpression to transtension: Oligocene Miocene structural evolution of the Vienna Basin and East Alpine-Western Carpathian junction. Tectonophysics, 242, 151182, 1995.

Franko, O., Remšík, A., and Fendek, M.: Atlas of geothermal energy in Slovakia. GÚDŠ, Bratislava, 1995.

Fusán, O., Plančár, J., and Ibrmajer, J.: Tectonic map of basement of Tertiary in Inner West Carpathians, in: Fusán, O., Biely, A., Ibrmajer, J., Plančár, J., and Rozložník, L. (Eds.): Basement of the Tertiary of the Inner West Carpathians GÚDŠ, Bratislava, 1123, 1987.

Gerner, P.: Recent stress field in Transdanubia (Western Hungary). Földtani Közlöny, 122, 89-105, 1992.

Gerner, P., Dövényi, P., Horváth, F., and Müller, B.: State of recent stress and seismotectonics in the Pannonian basin and surrounding areas. Terra Abstracts, 7, 123, 1995.

Gölke, M. and Coblentz, D.: Origins of the European regional stress field. Tectonophysics, 266, 11-24, 1996.

Gutdeutsch, R. and Aric, K.: Tectonic block models based on the seismicity in the East Alpine-Carpathian and Pannonian area, in: Flügel, H. W. and Faupl, P. (Eds): Geodynamics of the Eastern Alps. Deuticke, Vienna, 309-324, 1987.

Gutdeutsch, R. and Aric, K.: Seismicity and neotectonics of the East Alpine-Carpathian and Pannonian area, in: Royden, L. H. and Horváth, F. (Eds.): The Pannonian basin, a study in basin evolution. AAPG Memoir, 45, 183-194, 1988.

Haas, J., Kováč, S., Krystyn, L., and Lein, R.: Significance of Late Permian - Triassic facies zones in terrane reconstruction in the Alpine-North Pannonian domain. Tectonophysics, 242, 19-40, 1995.

Hók, J., Šimon, L., Kováč, P., Elečko, M., Vass, D., Halmo, J., and Verbich, F.: Tectonics of the Hornonitrianska kotlina Depression during the Neogene. Geologica Carpathica, 46, 191-196, 1995.

Hók, J., Kováč, P., Madarás, J., Maglay, J., Kováč, M., Baráth, I., Sabol, I., Slávik, M., and Lukaj, M.: Neotectonic and geomorphological evolution of the territory of Slovakia, part Geology (in Slovak). Manuscript report, Geol. Surv. Slov. Rep., Bratislava, 1-77, 1997. 
Hók, J., Kováč, M., Rakús, M., Kováč, P., Nagy, A., KováčováSlamková, M., Sitár, V., and Šujan, M.: Geologic and tectonic evolution of the Turiec depression in the Neogene. Slovak Geological Magazine, 4, 165-176, 1998.

Hók, J., Kováč, M., Kováč, P., Nagy, A., and Šujan, M.: Geology and tectonics of the NE part of the Komjatice depression. Slovak Geological Magazine, 5, 187-199, 1999.

Hók, J., Bielik, M., Vanko, J., Kováč, P., and Šujan, M.: Neotectonic character of Slovakia (in Slovak, English summary). Mineralia Slovaca, 32, 459-470, 2000.

Horváth, F.: Towards a mechanical model for the formation of the Pannonian Basin. Tectonophysics, 226, 333-357, 1993.

Horváth, F. and Cloetingh, S. A. P. L.: Stress-induced late-stage subsidence anomalies in the Pannonian Basin. Tectonophysics, 266, 287-300, 1996.

Hrašna, M.: Tectonic and seismic activity in the territory of Slovakia, in: Wagner, P. and Durmeková, T. (Eds.): Geology and environment. D. Štúr Publ., Bratislava, 107-109, 1998.

Janků, J., Pospíśil, L., and Vass, D.: Contribution of remote sensing to the knowledge of West Carpathians structure (in Slovak, English summary). Mineralia Slovaca, 16, 121-137, 1984.

Jarosiński, M.: Distribution of the contemporary stress field in the western part of the Polish Outer Carpathians (in Polish). Przeglad Geologiczny, 45, 768-776, 1997.

Jiřriček, R.: Structural evolution of the Carpathian arc during the Oligocene and Neogene (in Czech, English summary), in: Mahel', M. (Ed.): Tectonic profiles through the West Carpathians. Konf., Symp., Sem., GÚDŠ, Bratislava, 205-215, 1979.

Joó, I.: Recent vertical surface movement in the Carpathian basin. Tectonophysics, 202, 129-134, 1992.

Karner, G. D. and Watts, A. B.: Gravity anomalies and flexure of the lithosphere at mountain ranges. Journal of Geophysical Research, 88, 10449-10477, 1983.

Kárník, V., Michal, E. and Molnár, A.: Erdbebenkatalog der Tschechoslowakei bis zum Jahre 1956. Travaux Géophysiques, No. 69, Praha, 1957.

Kováč, M. and Baráth, I.: Tectonic-sedimentary evolution of the Alpine-Carpathian-Pannonian junction zone during the Miocene (in Slovak, English summary). Mineralia Slovaca, 28, 1-11, 1995.

Kováč, M. and Márton, E.: To rotate or not to rotate: Palinspastic reconstruction of the Carpatho-Pannonian area during the Miocene. Slovak Geological Magazine, 4, 75-85, 1998.

Kováč, M., Marko, F., and Nemčok, M.: Neogene structural evolution and basin opening in the West Carpathians. Geophysical Transactions, 37, 297-309, 1993.

Kováč, M., Baráth, I., and Nagymarosy, A.: The Alpine collapse of the Alpine-Carpathian-Pannonian junction - an overview. Acta Geologica Hungarica, 40, 241-264, 1997a.

Kováč, M., Bielik, M., Lexa, J., Pereszlényi, M., Šefara, J., Túnyi, I., and Vass, D.: The Western Carpathian intramountane basins, in: Grecula, P., Hovorka, D., and Putiš, M. (Eds.): Geological evolution of the Western Carpathians. Mineralia Slovaca Monograph, Bratislava, 43-64, 1997b.

Kováč, P. and Hók, J.: The Central Slovak Fault System - the field evidence of a strike slip. Geologica Carpathica, 44, 155-159, 1993.

Kováč, P. and Hók, J.: Tertiary development of the western part of Klippen Belt. Slovak Geological Magazine, 2/96, 137-149, 1996.

Krzywiec, P. and Jochym, P.: Characteristics of the Miocene subduction zone of the Polish Carpathians: results of flexural mod- elling. Przeglad Geologiczny, 45, 785-792, 1997.

Kvitkovič, J.: Intensity of vertical tectonic movements of the Earths crust in the Slovakian lowlands during the Holocene (in Slovak, English summary). Geografický Časopis, 45, 213-232, 1993.

Kvitkovič, J. and Plančár, J.: Analysis of morphostructures from the point of view of recent movement tendencies in relation to the deep geological structure of the Western Carpathians (in Slovak). Geografický Časopis, 27, 309-325, 1975.

Kvitkovič, J. and Plančár, J.: Recent vertical movements of the Earth crust in relation to earthquakes and seismic active faults in the Western Carpathians. Geografický Časopis, 29, 3, 1977.

Kvitkovič, J. and Vanko, J.: Recent vertical movements of the Western Carpathians for the epoch 1951-1976 (in Slovak, English summary). Geografický Časopis, 42, 345-356, 1990.

Labák, P. and Brouček, I.: Catalogue of macroseismically observed earthquakes on the territory of Slovakia (version 1996, in Slovak). Manuscript, Geophys. Inst. Slov. Acad. Sci., Bratislava, $15 \mathrm{pp}, 1996$.

Labák, P., Brouček, I., Gutdeutsch, R., and Hammerl, Ch.: The June 5, 1443 Central Slovakia earthquake. ESC XXV General Assembly, Abstracts, Reykjavik, p. 141, 1996.

Labák, P. Bystrická, A., Moczo, P., and Rosenberg, L.: Probabilistic seismic hazard computation for the Bohunice Nuclear Power Plant site. Manuscript, Geophys. Inst. Slov. Acad. Sci., Bratislava, 3-20, 1997.

Lankreijer, A. C.: Rheology and basement control on extensional basin evolution in central and eastern Europe: Variscan and Alpine-Carpathian-Pannonian tectonics. NSSG publication No. 980101, Amsterdam, 1-158, 1998.

Lankreijer, A. C., Bielik, M., Cloetingh, S. A. P. L., and Majcin, D.: Rheology predictions across the Western Carpathians, Bohemian Massif and the Pannonian Basin: implications for tectonic scenarios. Tectonics, 18, 1139-1153, 1999.

Lankreijer, A. C., Mocanu, V. and Cloetingh, S. A.P. L.: Lateral variations in lithosphere strength in the Romanian Carpathians: constrains on basin evolution. Tectonophysics, 272, 269-290, 1997.

Lexa, J., Konečný, V., Kalinčiak, M., and Hojstričová, V.: Distribution of volcanic rocks in the Carpathian-Pannonian region in space and time (in Slovak, English summary), in: Rakús, M. and Vozár, J. (Eds.): Geodynamic model and deep structure of the Western Carpathians. Konf., Symp., Sem., GÚDŠ, Bratislava, 57-69, 1993.

Maglay, J., Baňacký, V., Halouzka, R., Horniš, J., and Pristaš, J.: Geodynamic development of the Slovak regions during the Late Pliocene and Quaternary (in Slovak, English summary). Manuscript, GS SR, Bratislava, 1-43, 1993.

Mahel', M.: Geological structure of Czechoslovak Carpathians. Part 1: Paleoalpine units (in Slovak). Veda Publ., Bratislava, 1503, 1986.

Marčák, P., Vanko, J., Kubáček, L., Šterková, A., and Tóthová, A.: Map of recent vertical movements in the Western Carpathians (in Slovak). Manuscript, VÚGK, Bratislava, 1976.

Marko, F.: Faults in the Malé Karpaty, Považský Inovec, Strážovská hornatina and Nízke Tatry Mts (in Slovak). Manuscript, Glú SAV, Bratislava, 1-133, 1986.

Marko, F. and Kováč, M.: Reconstruction of the Miocene tectonic evolution of the Vadovce depression based on the analysis of structural and sedimentary record (Western Carpathians, in Slovak with English summary). Mineralia Slovaca, 28, 81-91, 1996.

Marko, F., Fodor, L., and Kováč, M.: Miocene strike-slip faulting and block rotation in Brezovské Karpaty Mts. Mineralia Slovaca, 
23, 201-213, 1991.

Marko, F., Plašienka, D., and Fodor, L.: Meso-Cenozoic tectonic stress fields within the Alpine-Carpathian transition zone: a review. Geologica Carpathica, 46, 19-27, 1995.

Márton, E. and Fodor, L.: Combination of paleomagnetic and stress data - a case study from North Hungary. Tectonophysics, 242, 99-114, 1995.

Milička, J., Pereszlényi, M., Šefara, J., and Vass, D.: Organic geochemical study of the junction zone of the Danube Basin and the Inner West Carpathians. First Break, 12, 571-574, 1994.

Milička, J., Pereszlényi, M., Franců, J., and Vitáloš, R.: Organic geochemical appraisal of hydrocarbon potential in the Danube Basin, Slovakia, in: Wessely, G. and Liebl, W. (Eds.): Oil and gas in Alpidic thrustbelts and basins of Central and East Europe. EAGE Special Publ., No. 5, Geological Society, London, 431439, 1996.

Mišík, M., Chlupáč, I., and Cicha, I.: Stratigraphic and historic geology (in Slovak). SPN, Bratislava, 304-344, 1985.

Müller, B., Zoback, M. L., Fuchs, K., Mastin, L., Gregersen, S., Pavoni, N., Stephanson, O., and Ljunggren, Ch.: Regional patterns of tectonic stress in Europe. Journal Geophysical Research, 97, B8, 11 783-11 803, 1992.

Nemčok, M., Hók, J., Kováč, P., Marko, F., Coward, M. P., Madarás, J., Houghton, J. J., and Bezák, V.: Tertiary development and extension/compression interplay in the West Carpathians mountain belt. Tectonophysics, 290, 137-167, 1998.

Nemesi, L., Šefara, J., Varga, G., and Kováčsvölgyi, S.: Results of deep geophysical survey within the framework of the DANREG project. Geophysical Transactions, 41, 143-159, 1997.

Onescu, M. C.: Deep structure of the Vrancea region, Romania, inferred from simultaneous inversion for hypocentres and 3-D velocity structure. Ann. Géophys., 2, 22-28, 1984.

Ord A. and Hobbs B. E.: The strength of the continental crust, detachment zones and the development of plastic instabilities. Tectonophysics, 158, 269-289, 1989.

Peresson, H. and Decker, K.: From extension to compression: Late Miocene stress inversion in the Alpine-Carpathian-Pannonian transition area. Mitt. Ges. Geol. Bergbaustud. Österr., 41, 75-86, 1996.

Plašienka, D., Putiš, M., Kováč, M., Šefara, J., and Hrušecký, I.: Zones of Alpidic subduction and crustal underthrusting in the Western Carpathians, in: Grecula, P., Hovorka, D., and Putiš, M. (Eds.): Geological evolution of the Western Carpathians. Mineralia Slovaca Monograph, Bratislava, 35-42, 1997a.

Plašienka, D., Grecula, P., Putiš, M., Kováč, M., and Hovorka, D.: Evolution and structure of the Western Carpathians: an overview, In: Grecula, P., Hovorka, D. and Putiš, M. (Eds.): Geological evolution of the Western Carpathians. Mineralia Slovaca Monograph, Bratislava, 1-24i, 1997b.

Pospíšil, L., Buday, T., and Fusán, O.: Neotectonic movements in the Western Carpathians (in Slovak, English summary). Západné Karpaty, Geológia, 16, 65-84, 1992.

Ratschbacher, L., Behrmann, J. H., and Pahr, A.: Penninic windows at the eastern end of the Alps and their relation to the intraCarpathian basins. Tectonophysics, 172, 91-105, 1990.

Ratschbacher, L., Merle, O., Davy, Ph., and Cobbold, P.: Lateral extrusion in the Eastern Alps. Part 1. Boundary conditions and experiments scaled for gravity. Tectonics, 10, 245-256, 1991a.

Ratschbacher, L., Frisch, W., Lintzer, H. G. and Merle, O.: Lateral extrusion in the Eastern Alps. Part 2. Structural analysis. Tectonics, 10, 257-271, 1991b.

Reichwalder, P.: Structural-geological map of CSSR (compiled based on cosmic images), 1:500 000 (in Slovak). Manuscript, PriFUK, Bratislava, 1984.

Réthly, A.: Earthquakes in the Carpathian basins 455-1918 (in Hungarian). Akadémiai Kiadó, Budapest, 1952.

Royden, L. H.: Late Cenozoic Tectonics of the Pannonian Basin System, in: Royden, L. H. and Horváth, F. (Eds.): AAPG Memoir 45: The Pannonian Basin. 27-48, 1988.

Royden, L. H.: The tectonic expression of slab pull at continental convergent boundaries. Tectonics, 12, 303-325, $1993 \mathrm{a}$.

Royden, L. H.: Evolution of retreating subduction boundaries formed during continental collision. Tectonics, 12, 629-638, 1993b.

Schenk, V., Schenková, Z., Kottnauer, P., Guterch, B., and Labák, P.: Earthquake hazard for the Czech Republic, Poland and Slovakia - contribution to the ILC/IASPEI Global seismic hazard assessment program. Natural Hazards, 21, 331-345, 2000.

Soták, J., Spišiak, J., and Biron, A.: Metamorphic sequences with "Bündnerschiefer" lithology in the pre-Neogene basement of the East Slovakian Basin. Mitt. Österr. Geol. Ges., 86 (1993), 111120, 1994.

Stankoviansky, M.: Relief evolution in the southern part of the $\mathrm{Tr}$ nava table (in Slovak, English summary). Geografický Časopis, 45, 93-107, 1993.

Stankoviansky, M.: Morphostructural units and their evolution of the Trnava upland in the surroundings of Jaslovské Bohunice (in Slovak, English summary). Geografický Časopis, 46, 384-398, 1994.

Szafián, P.: Gravity and tectonics: a case study in the Pannonian Basin and the surrounding mountain belt. NSG publication No. 980101, Amsterdam, 1-154, 1999.

Szeidovitz, G.: Earthquakes in the region of Komárom, Mór and Várpalota. Geophysical Transactions, 32, 255-274, 1986.

Šefara, J., Bielik, M., Konečný, P., Bezák, V., and Hurai, V. : The latest stage of development of the lithosphere and its interaction with the asthenosphere (Western Carpathians). Geologica Carpathica, 47, 339-347, 1996.

Šefara, J., Kováč, M., Plašienka, D., and Šujan, M.: Seismogenic zones in the Eastern Alpine-Western Carpathian-Pannonian junction area. Geologica Carpathica, 49, 247-260, 1998.

Šimon, L. and Halouzka, R.: Pútikov vŕšok volcano - the youngest volcano in the Western Carpathians. Slovak Geological Magazine, 2, 103-123, 1996.

Stohl, J.: The ores of the Central Slovak neovolcanics related to the Central Carpathian lineament. Západné Karpaty, Min., Petr., Geoch., Lož., 2, 7, 7-40, 1976.

Tari, G.: Alpine tectonics of the Pannonian Basin. PhD thesis, Rice University, Houston, 1-501, 1994.

Tari, G.: Extreme crustal extension in the Rába River extensional corridor (Austria/Hungary). Mitt. Ges. Geol. Bergbaustund. Österr., 41, 1-17, 1996.

Tari, G., Horváth, F., and Rumpler, J.: Styles of extension in the Pannonian Basin. Tectonophysics, 208, 203-219, 1992.

Tomek, Č. and Thon, A.: Interpretation of seismic reflection profiles from the Vienna Basin, the Danube Basin and the Transcarpathian Depresion in Czechoslovakia. AAPG Mem., 45, 171-182, 1988.

Tomek, Č., Ibrmajer, I., Koráb, T., Biely, A., Dvořáková, L., Lexa, J., and Zbořil, A.: Crustal structures of the West Carpathians on deep reflection seismic line 2T (in Slovak, English summary). Mineralia Slovaca, 21, 3-26, 1989.

Vanko, J.: A rectified map of recent vertical surface movements in the West Carpathians in Slovakia. Journal of Geodynamics, 10 , 
147-155, 1988.

Vanko, J. and Kvitkovič, J.: Map of recent vertical movement tendencies, in: Mazúr, E. (Ed.): Atlas of SSR. SAV, SÚGK, Bratislava, 1980.

Vanko, J. and Vyskočil, P.: The map of vertical crustal movement in Czechoslovakia and its interpretation. Journal of Geodynamics, 8, 143-150, 1987.

Varga, G. and Lada, F.: Magnetotelluric measurement on the profile 2T. Manuscript, ELGI Budapest - Geofyzika Brno, 1988.

Vozár, J., Szalaiová, V. and Šantavý, J.: Interpretation of the Western Carpathian deep structures on the basis of gravimetric and seismic sections, in: Rakús M. (Ed.): Geodynamic development of the Western Carpathians. Geol. Surv. Slov. Rep., D. Štúr Publ.,
Bratislava, 241-257, 1998.

Zoback, M. L.: First and second order patterns of stress in the lithosphere: the world stress map project. Journal of Geophysical Research, 97, 11, 703-729, 1992.

Zoetemeijer, R., Tomek, Č., and Cloetingh, S. A. P. L.: Flexural expression of European continental lithosphere under the Western Outer Carpathians. Tectonics. 18, 843-861, 1999.

Zsíros, T., Mónus, P., and Tóth, L.: Focal depth of Hungarian earthquakes. Gerlands Beitr. Geophys., 98, 146-154, 1987.

Zsíros, T., Mónus, P., and Tóth, L.: Hungarian earthquake catalogue (456-1986). Geodetic and Geophysical Research Institute, Hungarian Academy of Sciences, Budapest, 1988. 